\title{
Analysis of Determinants Exports and Spatial Linkages: A Case Study of Indonesian Frozen and Fresh Shrimp
}

\author{
Fitriani \\ Departement of economics \\ Faculty of Economics and Business, \\ University of Brawijaya \\ Malang, Indonesia \\ riririafitriani25@gmail.com
}

\author{
Dwi Budi Santosa \\ Departement of economics \\ Faculty of Economics and Business, \\ University of Brawijaya \\ Malang, Indonesia \\ dwibudisantosa@gmail.com
}

\author{
Putu Mahardika Adi Saputra \\ Departement of economics \\ Faculty of Economics and Business, \\ University of Brawijaya \\ Malang, Indonesia \\ putu@ub.ac.id
}

\begin{abstract}
This study aims to analyze the determinants of exports and the spatial linkages of frozen shrimp and Indonesian fresh shrimp. This research uses gravity model analysis and spatial autocorrelation analysis. The data used are panel data for the 2007-2017 period in 23 countries for frozen shrimp and 6 countries for fresh shrimp. The empirical findings from this study indicate that competitiveness, logistical performance, population, and exchange rates have a significant positive effect on frozen shrimp exports, while fresh shrimp exports are significantly affected by economic distance, population, rates, exchange rates, and FTAs. The moran's I index results in exports of frozen shrimp and fresh shrimp indicate a negative spatial autocorrelation.
\end{abstract}

Keywords—export, gravity model, spatial autocorrelation

\section{INTRODUCTION}

Fisheries and maritime affairs are one of the sectors that influence the acceleration of national economic development (Yusuf et al, 2017). Indonesian fishery products have become one of the non-oil and gas export commodities. The increase in exports is in line with the blue revolution movement which is a strategy to increase fisheries production, fishermen's income, and fisheries cultivation. Trade in fishery products has developed significantly in the last 60 years (FAO, 2013). According to FAO (2016) the supply of all types of fish and seafood increases and overall global seafood production grows at 3.5 percent every year. Seafood production targets have a market share of 37 percent of international trade (Natale et al., 2015). The ratio between sea trade and domestic product availability is estimated at 77 percent of world seafood production affected by world trade competition (Tveteras et al., 2012).

Shrimp commodities are the only fishery products included in the 10 main commodities of Indonesia's exports contributing to the trade balance surplus (Ministry of Trade, 2015). This is because shrimps are fisheries commodities that have high economic value and stable prices (Sunorita and Tjarsono, 2013). The high demand for world shrimp is in line with the increasing value of Indonesian shrimp exports. In 2017, shrimp commodities accounted for an export value of US $\$ 1,444,333,000$ or 44.15 percent of the total value of Indonesian fisheries. The export of shrimp commodity itself is divided into two types, there are fresh shrimp and frozen shrimp.

Indonesian fresh and frozen shrimp commodities experience a positive trend. The increase in exports of Indonesian fresh shrimp amounted to 323.18 percent in 2018 when compared to the value of exports in 2001, while for frozen shrimp was 53.04 percent. The significant increase in the value of fresh shrimp exports provide good news for Indonesian shrimp exports, however, the export value of frozen shrimp is 98.30 percent higher than fresh shrimp. Malaysia is the export destination for Indonesian fresh shrimp with an export value of US $\$ 4,240$ or 21.1 percent, followed by the United States of US \$4,186 thousand or 20.8 percent of the total exports of Indonesian fresh shrimp to the world. The export share of Indonesian frozen shrimp to America is US \$ 978,867 thousand with a total volume of 98,992 tons followed by Japan with 24,854 tons or 20.5 percent of Indonesia's total frozen shrimp exports to the world.

With the potential and market opportunities for export of Indonesian fresh and frozen shrimp in the export market, it is certainly inseparable from the availability of fresh and frozen shrimp in Indonesian marine and aquaculture waters. Both in terms of quantity and quality of fresh and frozen shrimp so that they can contribute positively to the export of Indonesian shrimp commodities in the global market. Exports of these commodities are measured by seeing how much the export opportunities of Indonesian fresh and frozen shrimp in the global market can improve the export performance of Indonesian fresh and frozen shrimp. Therefore it is necessary to ensure that the export of fresh and frozen shrimp commodities remain consistent and has increased.

Competitiveness is the most important thing in maintaining the consistency of exports of Indonesian fresh and frozen shrimp and increasing exports to destination countries. Studies on the competitiveness of Indonesian frozen shrimp exports are written by Syahfdi et al., (2010); Haryotejo, (2013); Yulianto and Mawardi, (2014); Aryudiawan, (2016); Ashari et al (2016); Silitonga et al. (2016) and Juarno et al. (2017) state that Indonesian frozen shrimp have a comparative advantage in the international market, as well as Indonesian fresh shrimp Maharani and Setiawina. (2012) and Ashari et al. (2016); This means that 
both Indonesian fresh and frozen shrimp can compete with the same commodities from other countries. However, the export of fresh and frozen shrimp in Indonesia is still low compared to the export value of fresh and frozen shrimp in Vietnam, India and China. In addition, Andriyanto et al (2013) showed that the competitiveness of Indonesia's frozen shrimp exports was low when it was compared to Thailand's frozen shrimp. This allows the competitiveness of Indonesian shrimp to be lower than in other countries.

In addition, logistical performance of Indonesia and its partner countries is an important factor in shrimp trade, considering that shrimp is one of the high-value and perishable commodities traded on the International Nature market (2016). Studies which is written by Bensassi et al (2015) and Gani (2017) showed that the logistics sector played an important role in the efficiency of trade. However, Kabak et al. (2018) showed that logistics performance did not affect the exports.

The pattern of world trade has undergone a shift from following the principles of supply-demand, but has also been shaped by issues, conventions, and international cooperation Saptanto and Soetjitpto (2010). This is done to prevent trade liberalization in order to strengthen the resilience of a country's economy against challenges and other economic blocks. Globalization and liberalization provide opportunities to increase domestic product access to the international market with a decrease in tariff and nontariff barriers.

Research related to international trade activities has been carried out quite a lot with behavioral modeling and potential estimates, especially exports. In its development the gravity model is the most popular empirical model used to explain bilateral trade relations, with various types of case studies on certain countries and commodities see (Apridar, 2015; Bose et al, 2019; Cheong et al, 2018; He et al, 2013; Li et al, 2008; Mailu et al, 2018; Natale et al, 2015b; Rabbani et al, 2011; Wiranthi et al, 2019). Although the gravity model has been widely used to explain bilateral trade behavior and activities, the aspect of spatial dependence is able to describe patterns of interaction between regions.

Based on the explanation, the purpose of this study is to determine the determinants of exports of Indonesian fresh and frozen shrimp in export destination countries and to know the spatial interaction patterns of exports of Indonesian fresh and frozen shrimp. It is hoped that this research can provide the input to the government so that appropriate steps are taken in an effort to increase exports of fresh and frozen Indonesian shrimp.

\section{RESEARCH METHODS}

\section{A. Data Source}

The research was conducted on the main destination countries for Indonesia's frozen shrimp exports, such as the United States, Japan, Singapore, Korea, Australia, Belgium, Canada, China, Denmark, France, Germany, Hong Kong, Italy, Malaysia, Netherlands, Russia, Spain, Sweden, Thailand, and English. While the destination countries for Indonesian fresh shrimp exports are Malaysia, Hong Kong, Singapore, the United States, Japan and Korea. Country selection is based on traditional country criteria according to the ministry of trade (DJPEN, 2013). Traditional countries are Indonesia's export destination countries which have carried out intensive trade for at least 10 years. The period's of research was chosen from 2007-2017 to illustrate the pattern of Indonesian exports of frozen shrimp and fresh shrimp.

\section{B. Empirical Model}

\section{1) Gravity Panel Model}

There are two equation models used in this study, namely the gravity panel model of exports of fresh and frozen shrimp:

$$
\begin{aligned}
& Y_{-} u s_{i j t}=\beta_{0}+\beta_{1} R C A \_u s_{i t}+\beta_{2} L P I_{i j t}+\beta_{3} P O P_{j t}+ \\
& \beta_{4} \text { Jarek }_{i j t}+\beta_{5} \text { Tarif }_{i t}+\beta_{6} E R_{i t}+\beta_{7} F T A_{i j t}+\mu_{i t} \\
& Y_{-} u b_{i j t}=\beta_{0}+\beta_{1} R C A \_u b_{i t}+\beta 2 L P I_{i j t}+\beta 3 P O P_{j t}+ \\
& \beta 4 J a r e k_{i j t}+\beta_{5} \text { Tarif }_{i t}+\beta_{6} E R_{i t}+\beta_{7} F T A_{i j t}+\mu_{i t}
\end{aligned}
$$

In managing the gravity panel model, there are several steps that must be done. The first step is to estimate panel data regression through several tests, that are the Chow test to select the best model between Pooled Least Square Model and Fixed Effect Model, Hausman test to choose the best model between Fixed Effect Model and Random Effect Model and Lagrange Multiplier Test to select the model best between Pooled Least Square Models and Random Effect Models. The last stage of the processing of the gravity panel data is to carry out the classic assumption test to see whether the equation has conformity with the assumption of classical regression or not. According to Jacob (2014) in panel data regression estimation analysis, the least squares method has limitation, there is its efficiency properties will lose if the panel data does not pass classical assumptions such as heteroscedasticity and autocorrelation. According to Blackwell, (2005) the error structure of these equations is assumed by heteroscedasticity panels, panel autocorrelation, and contemporary correlation. So the method that used are feasible generalized least square model (FGLS) and panel corrected standard errors (PCSE). The Generalized method is applied if it is assumed the variance of values in the model is known. However, the variance of values on the model is unknown so the model used is the FGLS method (Jacob, 2014).

TABLE I. DEFINITION OF OPERATIONAL VARIABLES AND DATA SOURCES

\begin{tabular}{|c|c|c|c|}
\hline Variable & Definition & Unit & Data Sources \\
\hline$Y_{-} u b$ & $\begin{array}{c}\text { Total frozen shrimp } \\
\text { exports to partner } \\
\text { countries }\end{array}$ & $\begin{array}{c}\text { US Dollar } \\
\text { thousand }\end{array}$ & UN Comtrade \\
\hline$Y_{-}$us & $\begin{array}{c}\text { Total fresh shrimp } \\
\text { exports to partner } \\
\text { countries }\end{array}$ & $\begin{array}{c}\text { US Dollar } \\
\text { thousand }\end{array}$ & UN Comtrade \\
\hline RCA_us & $\begin{array}{c}\text { Competitiveness of } \\
\text { fresh shrimp in } \\
\text { partner countries }\end{array}$ & $\begin{array}{c}\text { RCA } \\
\text { Index }\end{array}$ & $\begin{array}{c}\text { UN Comtrade, } \\
\text { processed }\end{array}$ \\
\hline RCA_wb & $\begin{array}{c}\text { Competitiveness of } \\
\text { frozen shrimp in } \\
\text { partner countries }\end{array}$ & $\begin{array}{c}\text { RCA } \\
\text { Index }\end{array}$ & $\begin{array}{c}\text { UN Comtrade, } \\
\text { processed }\end{array}$ \\
& \multicolumn{1}{|c}{} & \\
\hline
\end{tabular}




\begin{tabular}{|c|c|c|c|}
\hline $\begin{array}{c}\text { LPI (Logistic } \\
\text { Performance } \\
\text { Index) }\end{array}$ & $\begin{array}{c}\text { Infrastructure } \\
\text { between Indonesia } \\
\text { and partner } \\
\text { countries }\end{array}$ & LPI Index & $\begin{array}{c}\text { World Bank, } \\
\text { processed }\end{array}$ \\
\hline $\begin{array}{c}\text { Pop } \\
\text { (Population) }\end{array}$ & $\begin{array}{c}\text { Total population in } \\
\text { partner countries }\end{array}$ & People & World Bank \\
\hline $\begin{array}{c}\text { Jarek (Jarak } \\
\text { Ekonomi) }\end{array}$ & Transportation costs & $\begin{array}{c}\text { Economic } \\
\text { distance } \\
\text { index }\end{array}$ & CEPII, processed \\
\hline Exchange Rate & $\begin{array}{c}\text { Bilateral Exchange } \\
\text { Rate Value }\end{array}$ & \$/LCU & World Bank \\
\hline Tariff & $\begin{array}{c}\text { The exports cost of } \\
\text { fresh and frozen } \\
\text { shrimp }\end{array}$ & Percent & World Bank \\
\hline FTA (Free & $\begin{array}{c}\text { Indonesian free } \\
\text { trade agreement } \\
\text { with partner } \\
\text { countries }\end{array}$ & $\begin{array}{c}1=\text { have } \\
\text { an FTA } \\
0=\text { no } \\
\text { FTA }\end{array}$ & ADB, WTO \\
Agreement $)$ & \multicolumn{2}{|c}{} \\
\hline
\end{tabular}

\section{2) Spatial Autocorrelation}

Griffith (2003) explained about the concept of spatial autocorrelation. He said that there was no freedom between the observations but there was relationship between the condition at a spatial point and in the entire population. Spatial Autocorrelation shows a spatial relationship between one region and another (neighboring). Moran's I is a general statistical method used for testing autocorrelation in spatial data. Moran's I model is calculated using the following equation:

$$
I=\frac{N(x-\mu)^{\prime} W(x-\mu)}{S(x-\mu)^{\prime}(x-\mu)}
$$

According to Anselin (2010), if the spatial pattern shows a positive value, it means that the area is adjacent to the one-level region, namely the area with High-High and Low-Low patterns. Whereas if the spatial pattern shows the negative value of the region is neighboring with an area that is not one level, namely the region with HighLow and Low-High patterns.

\section{RESULTS AND DISCUSSION}

\section{A. Gravity Panel Model}

Based on the previous explanation about the gravity model analysis, then the coefficient values obtained from the estimation of all the independent variables that are presented in Table II. In accordance with these results, the export value of frozen shrimp and prawns can be formulated as follows:

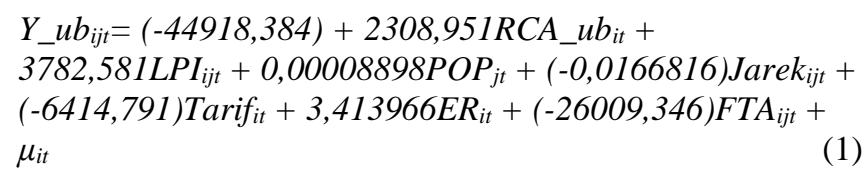

$$
\begin{aligned}
& Y_{u} u s_{i j t}=7570,1831+(-29,353356) R C A_{-} u s_{i t} \\
& +(-2528,4146) L P I_{i j t}+0,00003362 P O P_{j t}+ \\
& \text { o,00314004Jarek }_{i j t}+(-906,90739) \text { Tarif }_{i t}+11,9988256 E R_{i t} \\
& +2900,7742 F_{T A} A_{i j t}+\mu_{i t}
\end{aligned}
$$

All independent variables of frozen shrimp were noted to have a significant effect with a confidence level of $\alpha$ of $0.1 \%$ against the dependent variable. Whereas in fresh shrimp which has an influence at $\alpha=0.1 \%$ only population variables and tariffs. Variable of economic distance, exchange rate, and FTA significantly affect the export of fresh shrimp at $\alpha=1 \%$. The remaining LPI is significant with position $\alpha=5 \%$ and RCA does not affect the dependent variable.

TABLE II. Results of the GRAVITy Panel Model EStimation

\begin{tabular}{|c|c|c|}
\hline \multirow{2}{*}{$\begin{array}{c}\text { Independent } \\
\text { Variable }\end{array}$} & \multicolumn{2}{|c|}{ Dependent Variable } \\
\cline { 2 - 3 } & $Y_{-}$ub & $Y_{-}$us \\
\hline RCA & $2308,951 * * *$ & $-29,353356$ \\
\hline LPI & $3782,581 * * *$ & $-2528,4146 *$ \\
\hline Jarek & $-0,0166816^{* * *}$ & $0,00314004 * *$ \\
\hline Pop & $0,00008898^{* * *}$ & $0,00003362 * * *$ \\
\hline Tarif & $-6414,791 * * *$ & $-906,90739 * * *$ \\
\hline ER & $3,413966 * * *$ & $11,9988256 * *$ \\
\hline FTA & $-26009,346 * * *$ & $2900,7742^{* * *}$ \\
\hline Konstanta & $-44918,384$ & 7570,1831 \\
\hline
\end{tabular}

Based on table II shows that the RCA on frozen shrimp has a positive and significant effect on Indonesia's frozen shrimp exports to partner countries. This means that a 1 percent increase in frozen shrimp RCA will increase exports by 2308,951 findings in line with research by Ashari et al, (2016); Gunawan, (2015); and Juarno, (2012). While the RCA value of fresh shrimp has no significant negative effect on Indonesia's fresh shrimp exports to partner countries.

LPI variable shows that LPI in frozen shrimp has positive and significant effect on frozen shrimp exports. This means that an increase in 1 unit of the LPI index between Indonesia and partner countries will increase frozen shrimp exports by 3782,581 . This finding is in line with research by Bensassi et al. (2015); Gani, (2017); Lakshmanan et al, (2001). Meanwhile, LPI on fresh shrimp has a significant negative effect. This means that an increase in 1 unit of the LPI index between Indonesia and partner countries will reduce Indonesia's fresh shrimp exports by 2528.41. The findings are in line with Kabak research (2018) which states that the higher LPI of a country causes the higher trade costs which have an impact on exports.

The Jarek's variable or economic distance is the cost of trade transportation on the gravity model. Economic distance variable significantly influences the export of frozen shrimp and fresh shrimp of Indonesia. In frozen shrimp, a 1 percent increase in jarek will reduce exports by 0.01668 . This is in accordance with the law of gravity which states that the longer the distance the eating economy will reduce the intensity of trade. This finding supports Gunawan's research (2015); Ardiyanti and Saputri, (2018); and Widyastutik, (2013). Whereas for fresh shrimp, a 1 percent increase in jarek will increase exports by 0.00314 . This is not in accordance with the law of gravity but this finding is in line with the findings of Natale et al (2015) which states that the further the economic distance, the value of exports will increase.

Population variables have been widely used as economic measures in the gravity model. The results show that the population of partner countries has a positive and significant effect on exports of frozen shrimp and fresh shrimp in 
Indonesia. A 1 percent increase in the population of partner countries will increase frozen shrimp exports by 0.00008898 and fresh shrimp by 0.00003362 . This is in line with the law of gravity which states that a country's economic size has a positive and significant effect on exports and supports Andini's research, (2017); Baso, (2016); Hapsari and Haqqi, (2015); Juarno et al., (2017); Saptanto, (2011); Sulasmiyati and Gocklas, (2016); and Widyastutik, (2013).

The tariff is the cost of exporting frozen and fresh shrimp that is incurred by Indonesia's trading partner countries. The results show that the tariff has a negative and significant effect on Indonesia's frozen and fresh shrimp exports. This means that a 1 percent increase in tariffs will reduce frozen shrimp exports by 6414.79 and 906.907 in fresh shrimp. This is in line with the research of He et al (2013); Schmitz et al (2016); Nagurney et al (2018); Schwerhoff and Wehkamp (2018); Cheong et al (2018); Ardiyanti and Saputri (2018).

ER is a bilateral exchange rate value. ER's variable in this study is represented by $\$ / \mathrm{LCU}$ because export revenues are in the form of dollars. The results showed that ER had a positive and significant effect on exports of frozen shrimp and fresh shrimp in Indonesia. This means that a 1 percent increase in the trade partner exchange rate or the real exchange rate appreciates, which will increase frozen shrimp exports by 3.143 and fresh shrimp by 11.99 . This is in line with the statement of Krugman (2005) which shows the non-linear relationship between the exchange rate and the export value. This finding also supports the research of Petrovic (2010); Kurtovic (2017); Hoang (2018); and Gurtler (2018).

FTA is an agreement that is owned by Indonesia with partner countries which is represented by the dummy variable. The analysis shows that FTA has a significant effect on the export of frozen and fresh shrimp. This means that the FTA agreement between Indonesia and partner countries caused Indonesian frozen shrimp exports to fall by 26009.34. This is in line with research by Fani and Putri (2011); Setiawan (2012); Salam et al (2012) which shows that FTA ownership affects export decline due to the high value of imports from trading partners. Whereas the FTA agreement between Indonesia and partner countries has a positive effect on Indonesia's fresh shrimp exports of 2900.77, this finding is in line with the research of Setiawan (2010)

\section{B. Autokorelasi Spatial}

According to Longhi and Nijkamp (2007) the Moran's I statistical test can be used to answer whether the proposed model is able to present precisely the spatial relations between regions. Based on Moran's I test on the export of fresh shrimp and frozen shrimp as follows:

TABLE III. MORAN'S I TEST FOR SPATIAL CORRELATION ON FRESH AND FROZEN SHRIMP EXPORT

\begin{tabular}{|c|c|c|c|c|}
\hline Year & $\begin{array}{c}\text { Moran's I Fresh } \\
\text { Shrimp Export }\end{array}$ & p-value & $\begin{array}{c}\text { Moran's I Frozen } \\
\text { Shrimp Export }\end{array}$ & $\begin{array}{c}\text { p- } \\
\text { value }\end{array}$ \\
\hline $\mathbf{2 0 0 7}$ & -0.157 & $0.017 * *$ & -0.087 & 0.608 \\
\hline $\mathbf{2 0 0 8}$ & -0.197 & $0.003^{* *}$ & -0.090 & 0.610 \\
\hline $\mathbf{2 0 0 9}$ & -0.082 & 0.135 & -0.085 & 0.608 \\
\hline $\mathbf{2 0 1 0}$ & -0.036 & 0.107 & -0.081 & 0.605 \\
\hline $\mathbf{2 0 1 1}$ & -0.035 & 0.103 & -0.071 & 0.608 \\
\hline $\mathbf{2 0 1 2}$ & -0.020 & $0.092^{*}$ & -0.061 & 0.603 \\
\hline
\end{tabular}

\begin{tabular}{|l|l|l|l|l|}
\hline $\mathbf{2 0 1 3}$ & -0.196 & $0.014 * *$ & -0.058 & 0.635 \\
\hline $\mathbf{2 0 1 4}$ & -0.213 & $0.011^{* *}$ & -0.048 & 0.675 \\
\hline $\mathbf{2 0 1 5}$ & -0.194 & $0.012^{*} *$ & -0.068 & 0.637 \\
\hline $\mathbf{2 0 1 6}$ & -0.207 & $0.011^{*} *$ & -0.051 & 0.677 \\
\hline $\mathbf{2 0 1 7}$ & -0.234 & $0.013^{*} *$ & -0.048 & 0.684 \\
\hline \multicolumn{4}{|c}{ Note: ${ }^{*}$ Significance at level $0.1 * *$ Significance at level 0.05} \\
\hline
\end{tabular}

Based on table III shows that the results of Moran's I calculations for fresh shrimp are not significant in 2009 to 2011 , which were $-0.082,-0.036$, and -0.035 respectively. This means that during 2009 to 2011 there was no indication of export linkages between one country and its neighboring countries. Whereas in 2007, 2008, 2012 up to 2017 the value of Moran's I was significant (see table III) which showed that there were several indications of spatial linkages between countries in that year where destination countries with high export values are surrounded by smaller export destinations.
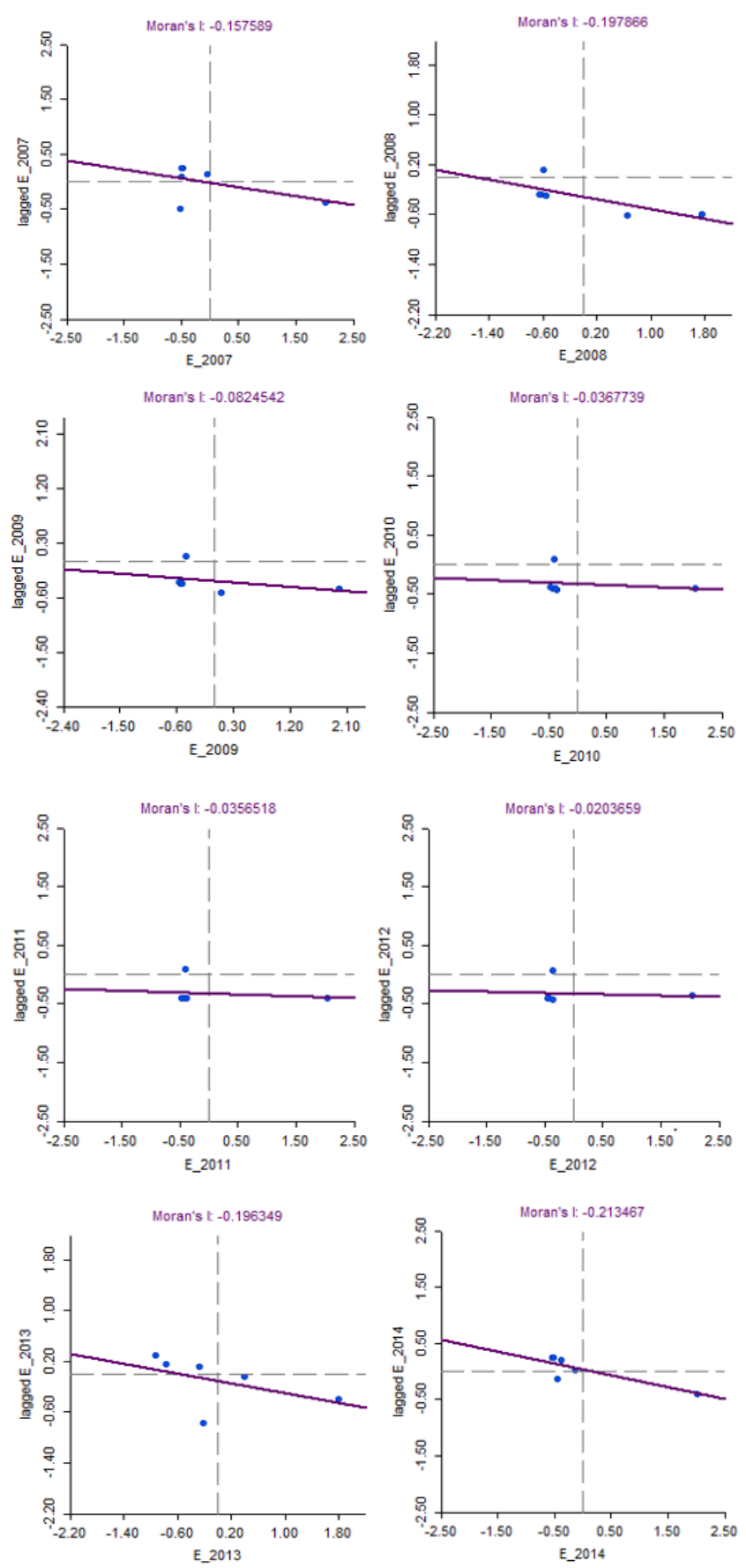

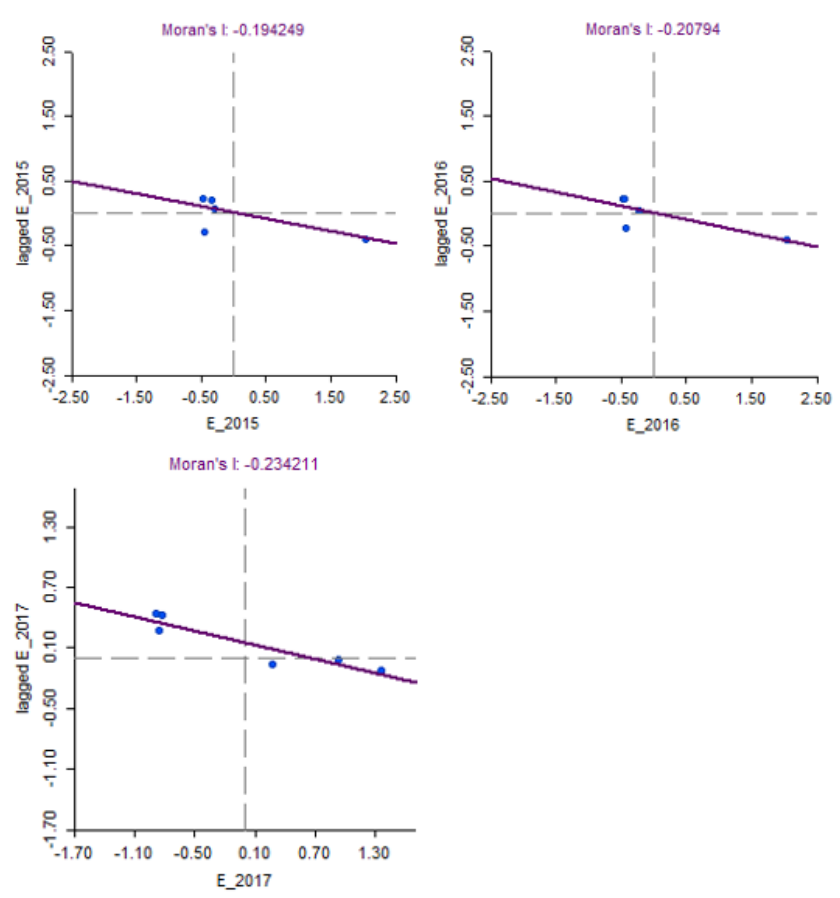

Fig. 1 Moran Scatterplots of Fresh Shrimp Exports from 2007 to 2017

TABLE IV. DISTRIBUTION OF COUNTRIES IN FOUR QUADRANTS ACCORDING TO FRESH SHRIMP EXPORT MORAN I IN 2007, 2009, 2011, 2013, 2017

\begin{tabular}{|c|r|r|r|r|r|r|}
\hline \multirow{2}{*}{ Quadrant } & \multicolumn{6}{|c|}{ Years } \\
\cline { 2 - 7 } & 2007 & 2009 & 2011 & 2013 & 2015 & 2017 \\
\hline High-High & - & - & - & - & - & - \\
\hline Low-High & - & - & - & - & - & Korea** \\
\hline Low-Low & - & Malaysia* & - & - & - & - \\
\hline High-Low & - & Japan** & - & - & - & - \\
\hline
\end{tabular}

The moran Scatterplots of Frozen Shrimp Exports (shown in fig.1) is the estimated Moran's I coefficient on the observed variables of fresh shrimp exports each year. The export of Indonesian fresh shrimp in destination countries is strongly influenced by the geographical location of the export partner countries. In table IV in 2009, Malaysia became the destination country for the export of fresh Indonesian shrimp in quadrant III or Low-Low, meant that countries which had low export value were surrounded by countries which its export value was also low. Meanwhile, Japan is the export destination of Indonesian fresh shrimp which has a high export value surrounded by areas that have a low export value so that they are in quadrant IV or High Low. In 2017 Korea is in quadrant II or Low-High, which means that the low value of Korean exports is surrounded by areas that have high export values.
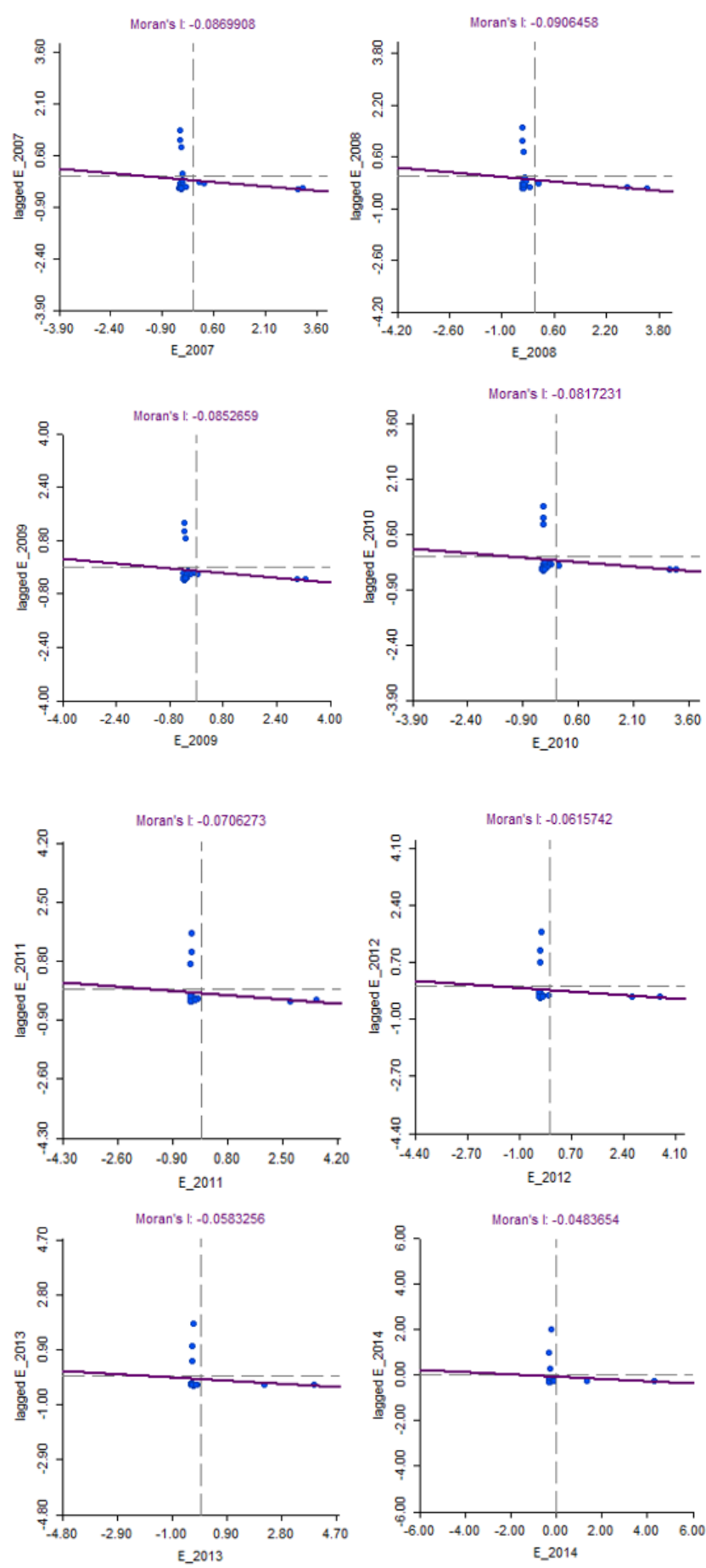


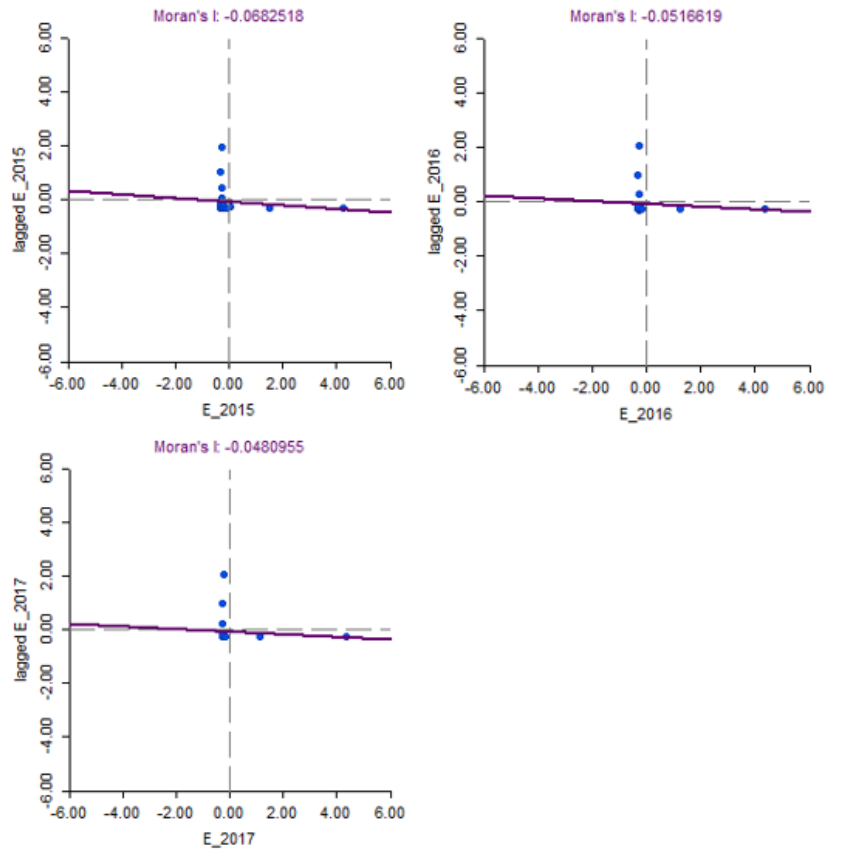

Fig. 2 Moran Scatterplots of Frozen Shrimp Exports from 2007 to 2017

TABLE V. DISTRIBUTION OF COUNTRIES IN FOUR QUADRANTS ACCORDING TO FROZEN SHRIMP EXPORT MORAN I IN 2007, 2009, 2011, 2013, 2017

\begin{tabular}{|c|c|c|c|c|c|c|}
\hline \multicolumn{2}{|c|}{ Quadrant } & $\begin{array}{l}\text { High- } \\
\text { High }\end{array}$ & \multicolumn{2}{|c|}{ Low-High } & Low-Low & $\begin{array}{c}\text { High- } \\
\text { Low }\end{array}$ \\
\hline \multirow{6}{*}{ Years } & 2007 & - & \multicolumn{2}{|c|}{ Rusia** } & Malaysia** & - \\
\hline & 2009 & - & \multicolumn{2}{|c|}{ Rusia** } & - & - \\
\hline & 2011 & - & Rusia** & Canada** & Australia** & - \\
\hline & 2013 & - & Rusia** & Canada** & & - \\
\hline & 2015 & - & Rusia** & Canada** & Australia** & - \\
\hline & 2017 & - & Rusia** & Canada** & Malaysia** & - \\
\hline
\end{tabular}

The moran Scatterplots of Frozen Shrimp Exports (shown in Fig. 2) are the estimated Moran's I coefficients on the variables of frozen shrimp exports each year observed. Indonesian frozen shrimp exports in destination countries are strongly influenced by the geographical location of export partner countries. In table V in 2007 until 2017 the Russian state is in quadrant II or Low-High means that the value of Russian exports is low surrounded by regions that have high export values, as well as the value of Canadian exports from 2011 to 2017. Malaysia and 2007 are the destination countries for Indonesian frozen shrimp exports are in quadrant III or Low-Low, which means countries that have low export value are surrounded by countries whose export value is also low, as well as Australia which is in quadrant III in 2011 and 2017.

\section{CONCLUSION}

From the results of the analysis of the models of Indonesian frozen and fresh shrimp exports using the gravity model can be summarized as follows:

1) All independent variables, namely RCA, LPI, economic distance (jarek), population (pop), rates, exchange rate (ER), and FTA significantly influence the export of frozen shrimp. Even so there are two variables which signs do not match the hypothesis such as the exchange rate and FTA.

2) Different results are found in fresh shrimp, namely RCA which does not affect exports. Other variables, namely LPI, economic distance, population, tariff, exchange rate, and FTA have a significant effect on their exports. However, there are more independent variables of fresh shrimp which contradict the hypothesis, namely LPI, economic distance, and exchange rate.

3) The value of Moran's I index for fresh and frozen shrimp in the range $-1<0<1 \leq 1$, it is shows negative spatial autocorrelation but the correlation can be solved because of zero, thus causing no spatial autocorrelation in the significance of the Moran index.

4) Based on of the significance test of the Moran Index with a significance level of $5 \%$, it can be concluded that between countries which do not have similarities to each other, indicate that fresh and frozen shrimp exports between those countries also have no correlation to each other.

\section{ACKNOWLEDGMENT}

The author would like to thank to Mr. Putu Mahardika Adi Saputa and Mr. Dwi Budi Santoso for guiding the author in completing this research. I also express my gratitude to the ministry of commerce for providing research related data and providing an opportunity for writers to attend the international conference.

\section{REFERENCES}

[1] Alam, N. S. . (2016). Safety in the Shrimp Supply Chain. Regulating Safety of Traditional and Ethnic Foods, 99-123. https://doi.org/10.1016/B978-0-12-800605-4.00006-2

[2] Andriyanto, F., Efani, A., \& Riniwati, H. (2013). Cobb-Douglass Analysis Of Production Factors Of Vannamei Shrimp ( Litopenaeus Vannamei ) Aquaculture Paciran Subdistrict Lamongan District, East Java, 1(1), 82-96.

[3] Apridar. (2015). The Competitiveness of Indonesian Tuna Export Facing The ASEAN Economic Community, 3(June 2014), 1-13.

[4] Aryudiawan, C. (2016). Daya Saing dan Kinerja Ekspor Produk Udang Indonesia ke Pasar Utama Udang Dunia 1996-2014.

[5] Ashari, U., Sahara, S., \& Hartoyo, S. (2016). Daya Saing Udang Segar dan Udang Beku Indonesia di Negara Tujuan Ekspor Utama, 13(1), 1-13. https://doi.org/10.17358/JMA.13.1.1

[6] Bensassi, S., Márquez-ramos, L., \& Martínez-zarzoso, I. (2015). Relationship between logistics infrastructure and trade: Evidence from Spanish regional exports. Transportation Research Part A, 72, 47-61. https://doi.org/10.1016/j.tra.2014.11.007

[7] Blackwell, J. L. (2005). Estimation and testing of fixed-effect paneldata systems. Stata Journal, 5(2), 202-207.

[8] Bose, S., Al Naabi, A. M. R., Boughanmi, H., \& Yousuf, J. B. (2019). Domestic Ban Versus Border Rejections: A Case of Oman's Fish Exports to the EU. SAGE Open, 9(1). https://doi.org/10.1177/2158244018823079

[9] Cheong, J., Kwak, D. W., \& Tang, K. K. (2018). The trade effects of tariffs and non-tariff changes of preferential trade agreements. Economic Modelling, 70(August 2017), 370-382. https://doi.org/10.1016/j.econmod.2017.08.011

[10] DJPEN. (2013). Laporan Akuntabilitas Kinerja

[11] FAO. (2013). State of World Fisheries and Aquaculture.

[12] FAO. (2016). State of World Fisheries and Aquaculture.

[13] Gani, A. (2017). The Asian Journal of Shipping and Logistics. The Asian Journal of Shipping and Logistics, 33(4), 279-288. https://doi.org/10.1016/j.ajsl.2017.12.012

[14] Griffith, D. A. (2003). Spatial Autocorrelation and Spatial 
Filtering: Gaining Understanding Through Theory and Scientific Visualization. Springer-Verlag Berlin Heidelberg.

[15] Haryotejo, B. (2013). Analisis Diversivikasi Pasar Ekspor Komoditas Udang Indonesia. Sosial Ekonomi Kelautan Dan Perikanan, 8(1), 85-91.

[16] He, C., Quagrainie, K. K., \& Wang, H. H. (2013). Determinants of shrimp importation into the USA: An application of an augmented gravity model. Journal of Chinese Economic and Business Studies, 11(3), 219-228. https://doi.org/10.1080/14765284.2013.814466

[17] Jacob, C. A. (2014). Analisis Model Regresi Data Panel Tidak Lengkap Komponen Galat Dua Arah dengan Penduga Feasible Generalized Least Square ( FGLS ), 4(1)

[18] Juarno, O., Oktaviani, R., Fauzi, A., \& Nuryartono, N. (2017). Kinerja Produktivitas dan Faktor yang berpengaruh terhadap Total Factor Productivity (TFP) Tambak Udang Indonesia. Jurnal Sosial Ekonomi Kelautan Dan Perikanan, 6.2, 149-168.

[19] Kabak, Ö., Ülengin, F., \& Önsel, Ş. (2018). Connecting logistics performance to export: A scenario-based approach, (May). https://doi.org/10.1016/j.retrec.2018.05.007

[20] Kemendag. (2015). Rencana strategis.

[21] Li, K., Song, L., \& Zhao, X. (2008). Component Trade and China's Global Economic Integration.

[22] Longhi, S., \& Nijkamp, P. (2007). Forecasting Regional Labor Market Developments Under Spatial Autocorrelation, 119(April), 100-119. https://doi.org/10.1177/0160017606298428

[23] Maharani, D. P. P., \& Setiawina, N. D. (2012). Volume Ekspor, Suku Bunga Kredit, kurs Dollar Amerika, Indeks RCA, 1-10.

[24] Mailu, S., Ngila, M., \& Wamukota, A. (2018). Tuna Fisheries and Trade within COMESA. Ssrn. https://doi.org/10.2139/ssrn.2827129

[25] Natale, F., Borrello, A., \& Motova, A. (2015a). Analysis of the determinants of international seafood trade using a gravity model. Marine Policy, 60, 98-106. https://doi.org/10.1016/j.marpol.2015.05.016

[26] Natale, F., Borrello, A., \& Motova, A. (2015b). Analysis of the determinants of international seafood trade using a gravity model. Marine Policy, 60, 98-106. https://doi.org/10.1016/j.marpol.2015.05.016

[27] Rabbani, A. G., Dey, M. M., \& Singh, K. (2011). Determinants of catfish, basa and tra importation into the USA: An application of an augmented gravity model. Aquaculture Economics and Management, 15(3), 230-244. https://doi.org/10.1080/13657305.2011.598215

[28] Saptanto, S., \& Soetjitpto, W. (2010). Analisis Model Ekspor Komoditas Perikanan Indonesia Dengan Pendekatan Gravity Model, 5(2), 169-181.

[29] Silitonga, Betrix; Hutagol, M. P. (2016). Faktor-Faktor yang Mempengaruhi Volume Ekspor Udang Putih (Penaeus Indicus) Indonesia Ke Hongkong serta Implikasi Kebijakannya. Jurnal Ekonomi Dan Kebijakan Pembangunan, 5(1), 1-24.

[30] Sunorita, M., \& Tjarsono, I. (2013). Kebijakan Hambatan Non Tarif Di Pasar Uni Eropa Terhadap Ekspor Komoditas Udang Indonesia, 1222-1232.

[31] Syahfdi, O. F., Siregar, (2010). Analisis permintaan pasar ekspor terhadap produk udang beku indonesia, 3(2), 8-16.

[32] Tveteras, S., Asche, F., Bellemare, M. F., Smith, M. D., Guttormsen, A. G., Lem, A., ... Vannuccini, S. (2012). Fish Is Food - The FAO's Fish Price Index. https://doi.org/10.1371/ journal.pone.0036731

[33] Wiranthi, P. E., Aminudin, I., \& Dewi, E. R. (2019). A Gravity Model for Indonesian Canned Tuna Exports to The European Union Market: An Application of PPML Estimator. Sriwijaya International Journal of Dynamic Economics and Business, 3(1), 31. https://doi.org/10.29259/sijdeb.v3i1.31-52

[34] Yulianto, E., \& Mawardi, M. K. (2014). Pengaruh Jumlah Produks Udang Indonesia, Harga Udang Internasional, dan Nilai Tukar Rupiah Terhadap Ekspor Udaang (Studi Volume Ekspor Udang Indonesia Tahun 2005-2014 ), 39(2), 67-73.

[35] Yusuf, R., Arthatiani, F. Y., \& Putri, H. M. (2017). Opportunities of Tuna Indonesia Export Market: A Bayesian Analysis Approach, (021) 